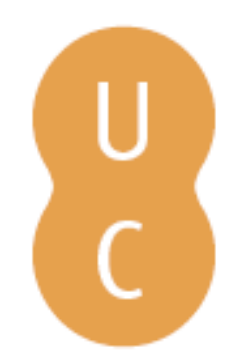

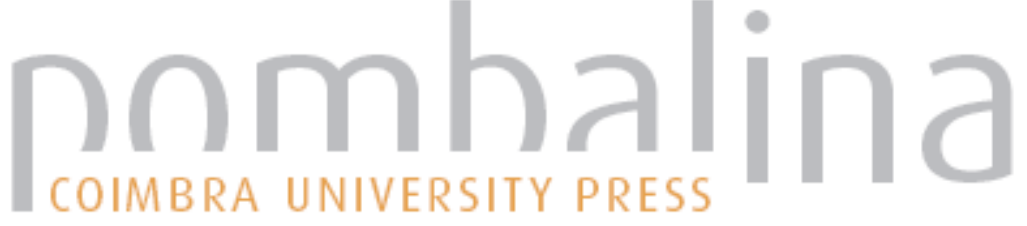

\section{Promoting quality in youth sports}

\author{
Autor(es): $\quad$ Marques, António; Oliveira, José \\ Publicado por: Coimbra University Press \\ URL \\ persistente: URI:http://hdl.handle.net/10316.2/32587 \\ DOI: $\quad$ DOI:http://dx.doi.org/10.14195/978-989-26-0412-1_2
}

Accessed : $\quad$ 26-Apr-2023 14:30:16

A navegação consulta e descarregamento dos títulos inseridos nas Bibliotecas Digitais UC Digitalis, UC Pombalina e UC Impactum, pressupõem a aceitação plena e sem reservas dos Termos e Condições de Uso destas Bibliotecas Digitais, disponíveis em https://digitalis.uc.pt/pt-pt/termos.

Conforme exposto nos referidos Termos e Condições de Uso, o descarregamento de títulos de acesso restrito requer uma licença válida de autorização devendo o utilizador aceder ao(s) documento(s) a partir de um endereço de IP da instituição detentora da supramencionada licença.

Ao utilizador é apenas permitido o descarregamento para uso pessoal, pelo que o emprego do(s) título(s) descarregado(s) para outro fim, designadamente comercial, carece de autorização do respetivo autor ou editor da obra.

Na medida em que todas as obras da UC Digitalis se encontram protegidas pelo Código do Direito de Autor e Direitos Conexos e demais legislação aplicável, toda a cópia, parcial ou total, deste documento, nos casos em que é legalmente admitida, deverá conter ou fazer-se acompanhar por este aviso.

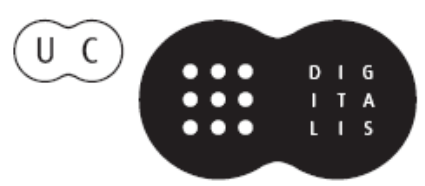


MANUEL COELHO E SILVA

ROBERT M. MALINA

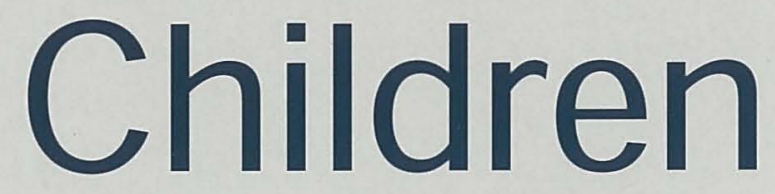

\section{and Youth}

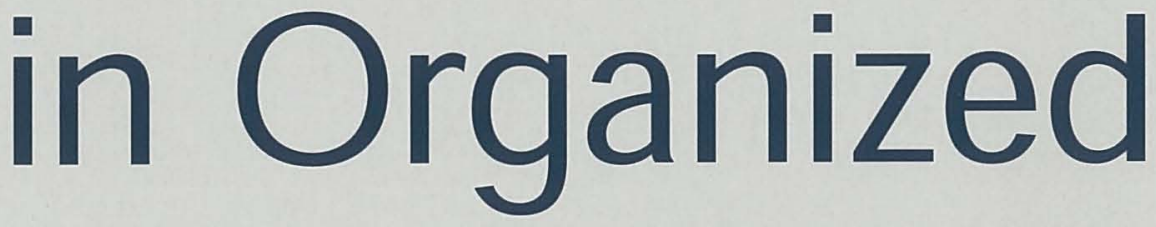

Sports 
(Página deixada propositadamente em branco) 
Manuel Coelho e Silva

Robert M. Malina

(Editors)

CHILDREN AND YOUTH IN ORGANIZED SPORTS

COIMBRA UNIVERSITY PRESS

2004 


$$
\begin{gathered}
\text { Editors } \\
\text { Manuel Coelho e Silva } \\
\text { and } \\
\text { Robert M. Malina } \\
\text { Publisher } \\
\text { Imprensa da Universidade de Coimbra } \\
\text { Coimbra University Press } \\
\text { Title } \\
\text { Children and Youth in Organized Sports }
\end{gathered}
$$

Date

March 2004

ISBN

972-8704-21-6

(Depósito legal n.: 208058/04)

Financial support

FCT Fundação para a Ciência e a 'Tecnologia MINISTÉRIO DA CIÊNCIA E DO ENSINO SUPERIOR Portugal

$$
\text { Apoio do Programa Operacional }
$$

Ciência, Tecnologia, Inovação do Quadro Comunitário de Apoio III

e

Câmara Municipal da Lousã

Faculdade de Ciências do Desporto e Educação Física

Universidade de Coimbra 


\title{
PROMOTING QUALITY IN YOUTH SPORTS
}

\author{
António Marques \\ José Oliveira
}

Faculty of Sport Science and Physical Education. University of Oporto.

PORTUGAL

\section{INTRODUCTION: THE CHALLENGE FOR QUALITY}

In the last few years, debate among experts and coaches has focused on the quality of youth sport programs. Underlying motivations are the special training needs of children and youth, and the continuous search for better results in sport.

There is no quality in youth sport programs without well-prepared, qualified coaches. The preparation of coaches requires an appropriate theoretical framework based upon knowledge produced by scientific and empirical research. However, much of the research dealing with the practices of coaches has not always been satisfactory and errors have been made based on research.

Several key aspects of the debate on quality in youth sport programs are subsequently considered. In youth sport, quality demands that coaches are prepared to think and understand sport far beyond the immediate results of competition. A coach's commitment to youth sport should be understood within the framework of pedagogical and moral (ethical) responsibility preparing youth for the future.

Parents, communities and society at large expect coaches to be competent and responsible in offering opportunities for youth to practice sport and to develop abilities and qualities under safe conditions within a sound social environment regarding moral and ethical principles. On the other hand, it is not acceptable for coaches, parents and/or staff to use youth activities as an instrument to achieve their own expectations, interests and objectives to the detriment of the developmental needs of youth.

Coaches should be required to improve their practices in the leadership of youth sport programs. They should not only be expected to accomplish specific sport tasks, but should be expected to be responsible and competent to prepare youth for future life. This requires that coaches are familiar with the biological, psychological and social characteristics of growth and development during childhood and adolescence, and can integrate this knowledge into their practice. Coaches should also be prepared to organise sport activities under 
appropriate pedagogical principles and ethical values. In this way, coaches can prepare young athletes not only for the demands of future top level sport but also for life in general. These tasks are highly demanding from the technical and physical points of view, and also require a strong moral foundation to face the demands of professional sport.

What is a competent coach? Is he/she the one who achieves the best competition results with young athletes? As already noted, results are not the most effective criterion to evaluate the competence or quality of a coach. Other criteria are required.

Meinberg (199|) proposed the following perspective. The competent coach in youth sport programs is not the one who achieves immediate results in competition throughout an early intensive specialisation, but the one who succeeds in bringing to the higher stages of top level sport the great number of young athletes. In competitive sport, results obtained in early stages of youth preparation have no social relevance if they limit the possibilities for advancement through the stages of a sport career. Winning is important for children and adolescents, but it can not be so important for coaches.

If we want to assess coach competence, several questions should be asked. Among the young athletes coached, how many have succeeded, some years later, in reaching the higher stages of top level sport? How many of a coach's young athletes are still involved in top level training?

It was suggested for a long time that simply increasing the number of hours and years of training would, as a consequence, result in better performance in high levels. A direct relationship between training volume and performance quality in advanced stages of a sport career was assumed (Bremer, 1986). The error in this assumption is now being gradually understood. Training strategies based strictly on increasing load volume, with no emphasis on the load quality, led to poor results in advanced stages and perhaps contributed to increasing rates of drop out.

High performance at the top level depends mostly on what was done in the initial stages and not so much on the number of years of training. Toplevel results are apparently influenced by the quality of the loads rather than by the number of hours in training. However, further evidence is needed to confirm this assertion. Nevertheless, even if it could not be confirmed, it is necessary for coaches of youth to change this approach.

The daily life of children and adolescents is filled with a variety of activities in education, sport, music, dance, foreign language acquisition, computer training, and so on, in addition to normal social demands of peers and family. These needs are important to youth development and limit the 
time available for sport training. Coaches should not encourage youth to sacrifice these activities in order to concentrate on sport.

The interests of young people are becoming more and more diverse. Moreover, parents are aware that their child's chance for a successful career in sport depends on the opportunities provided in the first years of formation, but that opportunities for such careers are extremely few.

Hence, the promotion of the interest and enjoyment in sport activities should constitute a priority for coaches (Rahn, 1993). This implies that coaches carefully choose training methods and content.

What motivates a 10 year old child to swim non-stop 2 hours a day, 7 days a week? Is such a monotonous training program necessary for success in swimming? Can the great number of dropouts from such programs be avoided?

Methods based on games are viewed by some pedagogues (Kurz, 1988; Marques, 1995; Rost, 1995) as a very important strategy to promote an athlete development in the early stages of preparation. Marques et al. (2000), for example, analysed 981 training units of Portuguese young athletes, 10-15 years, in several team sports - basketball, soccer, team handball and volleyball. In the age group 10-12 years, coaches used most of the time (55\%) in training methods not based on the game approach.

Promotion of quality demands the choice of more interesting activities which may bring even more young people into sport practice. It also assumes that coaches will be able to do their best using more effective methods in the particular sport activity to provide better work and to achieve more effective results.

The aim of this paper is to address recent theoretical developments which may help coaches promote quality in youth sport programs. Quality is a word that is part of daily vocabulary, but has different meanings among individuals and contexts. The term quality is in many ways an elusive and abstract concept (Carman, 1990). For the present discussion, the promotion of quality refers to the improvement of the effectiveness of training as suggested by Martin (1991): "for the same work, more effectiveness in the results." The subsequent discussion considers improvement in the quality of training in the context of the following variables: sport technique, decision making processes in sport activity, speed training, training load, and sport competition. 


\section{PATHS TO QUALITY IN YOUTH SPORT PRACTICES}

Both the individual and sport performance are complex realities. Athletic performance depends on bio-psycho-social determinants. The interactions of bio-energetic and informational processes, which are influenced by cognition, will and emotion, are central. However, in most cases, neither the practices of coaches nor the models that underlie the methods are committed to this view. Both theory and practice of sport training focus largely on the "principle of load-adaptation of the bio-energetic systems" (Bauersfeld, 1991). Even if information processes are perceived as an important factor for the practice of a sport, they are often not considered, which is erroneous. This is especially important for children who are learning a sport. These ages are a sensitive period for motor learning in general and for the acquisition of sport fundamentals in particular. Sensorimotor and cognitive aspects need to be emphasised in sport practice during childhood.

As a general principle, training priorities before puberty should be oriented to the informational dimension - decision and co-ordination mechanisms - of the sport activity. After puberty priorities should focus on the metabolic and muscular dimensions (Martin, 1991; Martin et al., 1993; Rost, 1995; Marques, 2000). Accordingly, several aspects of improved quality in the training of children and adolescents are subsequently considered:

- Improvement of sport technique

- Choice of adequate decisions during sport activities

- Improvement of speed training

- Choice of appropriate loads

- Development of the competitive system.

\section{IMPROVING SPORT TECHNIQUE}

The process of improvement of sport technique was always considered a major issue in youth training and because of this was regarded in most sport disciplines as a key factor of the activity programs. In general, specific technique models were developed for youth training starting based on the demands of top level sport; technique training became a more and more autonomous training complex in youth sport programs; technique training was being supported by theoretical assertions; and youth competition often integrated complexes of different techniques (Bauersfeld, |991).

Further aspects of technique training need consideration. First, a major role should be played by movement regulation and control. The demands related to sport technique research and knowledge development, particularly 
movement representation and perception, should be emphasized. Second, technique training and motor learning should not be viewed from a narrow perspective. On the contrary, they should be organized in an integrative relationship with other motor, decisional and energetic demands of the specific sport activity. However, interactions between the latter and technique training are seldom considered in an adequate manner. Experts and researchers need to more carefully consider these issues, focusing attention on the demands of the coordination and learning processes. Improving quality in the future should be based on defining new training orientations and principles that focus on a continuous increase of the degree of difficulty of the coordination and motor learning demands (Martin, 199I).

\section{EMPHASING THE ROLE OF THE DECISIONAL PROCESSES DURING SPORT ACTIVITIES}

In youth programs and particularly tactic/strategy sports, decision making in sport actions should be a major objective. It is very important that in all stages of the process of sport preparation, young athletes can play an active and conscious role in the learning and training. This implies that coaches focus more on situations that can be stimulating for learning and that can help youth to choose adequate options during sport activities. It also implies that coaches do not always provide youth the answers needed to resolve the problems they face in sport activities. Coaches must be able to objectively define what they want youth to learn in each stage of the training process and to help youth to make the right decisions by formulating the principles and orientations that guide decision-making. This will promote a more effective learning/decision making process.

A great variety of the activities offered to youth in training and competition are not the most adequate and do not properly stimulate the sport learning process. They are often too complex for youth who are not yet either able or prepared to respond to these demands. Team sports, for instance, require attention, anticipation, decisions and quick responses, which are cognitive competencies that are not completely developed in children under 10 years of age (SMPC, 2000).

Good learning processes are those that stress active and conscious participation by setting problems and providing youth with opportunities to experience a diversity of situations, e.g., rejecting some options and choosing others among the possible solutions, and not those that are strictly dependent on feedback from coaches, as happens very often. Using the example of team sports, if a coach wants athletes in top level stages to respond quickly and correctly to game demands, he/she needs to prepare them appropriately since the early stages of the learning/training process. The athletes should be 
prepared to respond with short reaction times and in reduced game areas because time and space for play are not readily provided by opponents.

\section{INCREASING MOVEMENT'S SPEED DURING SPORT ACTIONS}

Speed training is a priority in many youth sport programs (Bauersfeld, 1991; Martin, 1991; Rost 1995; Marques and Oliveira, 2001). However, some coaches do not focus on speed abilities.

An analysis on the structure of training sessions of young Portuguese athletes $10-12$ years in several team sports indicated that speed abilities play a minor role - only $5 \%$ of training's total time, $2.5 \%$ to reaction speed, $0.7 \%$ to movement speed and 2.3\% to maximal speed (Marques et al., 2000). Because speed abilities are important to the formation of young athletes (Bauersfeld, 1991; Martin et al, 1993; Martin, 1999), they should be prioritized in close relation to technique and tactic/strategy formation. However, this happens neither on a regular basis nor in the proper manner. Most of the time, emphasis is oriented to the muscular and metabolic components of speed and less to the aspects that depend on control and regulatory mechanisms of the nervous system. The latter emphasis is more adequate for children because at this stage are in a sensitive period for the development of coordination processes.

Maturation of the nervous system takes place earlier than the maturation of the metabolic and muscular systems, which are generally ready to support intensive loads after puberty. The development of the functional mechanisms of neuromuscular and nervous systems which control fast movements do not occur in a natural manner, i.e., as a maturation process (Rost, 1995). On the contrary, they occur in close relation to the activities that children experience during this period of development. Thus, if a coach wants to stimulate these mechanisms, appropriate situations should be selected. This can be done, for example, by adopting competitive models that reduce the game area (small games) or by reducing the distances.

In Germany, young long distance swimmers compete often over short distances such as 25 or 50 meters no matter the stroke. In the United States, young swimmers do not ordinarily participate in long distance competitions (Rost, 1995).

The improvement of speed training methods should be understood as a major priority in youth sport because this ability is a determinant of top level performance in most sport disciplines. But before puberty, training methods should stress the information systems in relation to the sensitive period of coordination and sport technique. 
The development of a superior organisation of the nervous system and the stimulation of neuromuscular regulation and control mechanisms through fast and intensive sport movements should be done during maximal load exercises and movements under time pressure, as happens during competitive situations. However, these kinds of situations also increase the number of coordination errors. As a consequence, coaches need first to assure correct execution of motor skills and sport techniques. The degree of complexity of many competitive actions and exercises, and the low level of development of the energetic and muscular systems do not always allow specific speed training based on competitive exercises. Taking this into account, the strength demands of speed exercises can be reduced and exercises that allow higher movement speed can be emphasized so that youth can easily and quickly identify and respond to game demands (Bauersfeld, 1991). The importance of a systematic improvement of intra- and inter-muscular coordination throughout fast muscle contractions during situations of reduced resistive training should be emphasized (Martin, 1991).

In such situations, motor transfer to specific sport practices is not negatively influenced if the training exercises are similar to the competitive activities. This is why loads under time pressure should be used on a regular basis in youth sport programs in all training situations and not only during speed training.

\section{CHOOSING THE MORE APPROPRIATE LOADS}

Results in high level stages do not depend on the continuous increase of load volumes in youth programs. There is a need to better identify appropriate loads for youth training. This requires more careful choice of both load and content of training (Martin, 199I). In an attempt to build of a new model for training loads in youth sport programs, four main orientations are suggested:

\section{(i) Preparing young athletes to support high loads in top-level stages}

Good results in top level sport should not be expected without very intensive loads. Young athletes need to be prepared to support such loads when they reach advanced stages. By using multilateral loads in youth sport programs, coaches can enhance and strengthen the basis that allows, some years later, the application of very intensive loads. This will presumably improve results and reduce impacts of such loads on the body.

\section{(ii) Stressing a specific multilateral load}

Some formulations of training theory suggest that the adaptive potential of the organism is limited to so-called "adaptation reserves" (Martin, 1991). For this reason, the spectrum of factors to be trained must be limited to the 
relevant demands of a competition in the specific sport. General training should thus aim at the specific demands of each sport (Bauersfeld, 199I; Rahn, 1993; Marques, 1999; Marques et al., 2000).

Accordingly, coaches need to use multilateral loads by increasing the capacity levels of specific performances through the choice of appropriate exercises. Such a program promotes both the objectives of general training and transfer effects from general to specific exercise.

(iii) Focusing on quality of training loads

Improving the quality of training loads requires concentration on those components of the performance which are essential for top level sport in each discipline. These components are understood as pre-requisites for the opening of new reserves of sport performances which are not properly stimulated during the formation stages.

If these components have such an essential role, they need to be defined for each sport discipline and the periods (times) when they can be properly stimulated during the long term process of athlete development need to be identified. If specific training does not take place during these particularly sensitive periods, it will be likely very difficult to do so later.

(iv) Individualisation

Finally, the focus on quality also requires the establishment of conditions that allow a stronger individualisation of the coaching process (Martin et al., 1993). Such individualisation is one of the major possibilities for promoting quality.

\section{THE DEVELOPMENT OF THE COMPETITION SYSTEM}

The increasing social relevance of youth sport over the last four decades or so and the search for better solutions to the process of sport specialisation has resulted in the development of a youth competition at the regional, national and international levels. Although youth training systems have improved, the same cannot be stated about the system of competitions.

38 There is a lack of theory dealing with youth competitions. In most cases, competition models are very traditional and conservative. They are quite similar in organisational form and content to competitions in top level sport. This is unfortunate because the demands of these competitions are very high and the possibilities for child and adolescent athletes are not the same as for adult athletes.

More precise formulations of a competition theory for youth are needed. These may include, among others, the following: 
- $\quad$ Function and objectives of youth sport competitions

- $\quad$ Types of competitions for different stages of development and preparation

- Number and frequency of competitions during each phase of sport formation

- $\quad$ Organisation, regulation and content of competitions at different stages of sport preparation

- Relationships between training and competition at different stages of sport preparation.

There is much work to be done to improve the quality of youth sport competitons. This will require the contributions and efforts of researchers from all disciplines of the sport sciences and experts in youth sport in building of a sound competition theory.

Training and competition are the two main subsystems of sport, and by definition they are related. Theories and models of training and of competition for children and adolescents need to be developed jointly.

Continued application of the specialized competition models of adult and top level sport to youth will undoubtedly result in premature specialization of children and adolescents. The specialised demands of competition with emphasis on results necessarily requires specialisation of the training process, which has as a consequence premature increase of load volumes and intensities to levels that are not appropriate for children and adolescents and for the objectives of youth sport formation. Overuse injuries and other negative implications for development and health are often outcomes of such efforts.

As a result, several European researchers and pedagogues have focused on the contents of competitive activities during early stages of development in an attempt to formulate a more adequate and harmonious relationship between the contents of training programs and the contents of competitive activities (Thieß, 1991, 1995; Rost, 1995; Tschiene, 1995, Marques, 1997; Lima, 2000; Marques and Oliveira, 2002). If both training and competition in youth sport programs are to be understood primarily as a means for formation, the practice of training and competitive exercises needs to be brought into the same framework.

Pedagogical guidelines for the early phases are oriented to the idea of diversity in activities and are aimed at promoting multilateral development. The same should occur in competitive sport activities. They should be considered as a training means, constituting a highly motivating stimulus to 
children and offering them the chance to participate in a variety of competitive activities, either formal or informal, highly structured or unstructured, in accordance to the objectives of sport formation during the early stages.

In summary, in each phase of the long term process of sport preparation, there should be a balanced, coherent relationship between the content of the activities in training and in competition according to the following orientation:

- Stages of multilateral training - multilateral competitions,

- Stages of adapted specialised training - adapted specialised competitions,

- Stages of highly specialised training - highly specialised competitions.

\section{OVERVIEW AND IMPLICATIONS FOR TEACHING AND COACHING}

The debate on the quality in youth sport programs will continue. Many other topics contribute to make this debate more significant. It is important to be aware that children and adolescents in sport are the subjects and not only the objects of intervention by coaches. Implications for teaching and coaching include the following, among others:

Continued improvement of teaching and learning methods of sport techniques focusing on movement regulation and control processes and emphasising the role of movement representation and perception. On the other hand, technique training should be planned in an integrative manner with other demands of sport activity.

- Emphasis on the role of decisional processes during sport activities by setting appropriate problems and providing opportunities that offer children and adolescents possibilities to choose the best solutions during each situation.

Give speed training high priority in youth sport programs by focusing on control and regulation mechanisms of this ability during childhood rather than on the metabolic and muscular mechanisms, which should be emphasised after puberty.

Choose more appropriate training loads in youth sport programs by planning load dynamics according to three main principles: (a) children and adolescents should be prepared to support very intensive loads in top level stages; (b) multilateral loads specifically oriented to the specialised demands of a chosen sport should be 
used; and (c) focus should be on the quality of training loads by identifying those components of top level performance which are essential to top performance and work on them during the right periods of the long term process of sport formation.

Finally, emphasize the fact that adult competitions are much too demanding for children and adolescents, and that competitive activities in youth sport programs should be organised according both to formation objectives and the needs of the young athletes.

\section{LITERATURE}

Bauersfeld K-H (|99|). Tendenzen der Weiterentwicklung des Kinder- und Jugendtrainings. In H. Kirchgässner (Hrsg.) 40 Jahre Deutsche Hochschule für Körperkultur Leipzig. Sankt Augustin, Academia. Alemanha, pp. 82-92.

Bremer D (1986). Wettkampfsport im Grundschulalter. Leistungssport 2: 5-10. Münster: Deutscher Sportbund, Philippka-Sportverlag.

Carman, J. M. (1990). Consumer perceptions of service quality: an assessement of SERVQUAL dimensions. Joumal of Retailing, 66:33-55.

Kurz D (1988). Pädagogische Grundlagen des Trainings. Studienbrief 4 der Trainerakademie Köln, Schorndorf: Hofmann-Verlag.

Lima T (2000). Competiç̃es para jovens. In CEFD (Ed) O melhor da revista Treino Desportivo. Lisboa: CEFD, pp. 235-248.

Marques A (1995) O desenvolvimento das capacidades motoras na escola. Os métodos de treino e a teoria das fases sensíveis em questão. Horizonte 66:212-216.

Marques A (1997). A preparação desportiva de crianças e jovens. O sistema de competições. In Guedes O (Org.) Atividade Física: uma abordagem multidimensional. João Pessoa: Ideia, pp. I57- 69.

Marques A (1999) Crianças e adolescentes atletas: entre a escola e os centros de treino... entre os centros de treino e a escola. In Adelino J, Vieira J, Coelho $O$ (eds) Treino de Jovens. Lisboa: CEFD. Secretaria de Estado do Desporto, pp. 17-30.

Marques A (2000) Sobre as questões da qualidade no treino dos mais jovens. In FM Silva (Org.) Produção do Conhecimento no Treinamento Desportivo: Pluralidade e Diversidade. João Pessoa: UFPB, Editora Universitária, pp. 5 I-59.

Marques A, Maia J, Oliveira J, Prista A (2000). Training Structure of Portuguese Young Athletes. In A Prista, A Marques, J Maia (Org.) 10 Anos de Actividade Cientifica. Faculdade de Ciências de Educação Física e Desporto, Lisboa: Ministério da Juventude e Desporto, Colecção Estudos, pp. 270-279.

Marques A, Oliveira J (200 I). O treino dos jovens desportistas. Actualização de alguns temas que fazem a agenda do debate sobre a preparação dos mais jovens. Revista Portuguesa de Ciências do Desporto, I (I): I 30- I 37. Porto: FCDEF-UP.

Marques A, Oliveira J (2002). O treino e a competição dos mais jovens: rendimento versus saúde. In $\vee$ Barbanti, AC Amadio, J Bento, A Marques (Eds) Esporte e Atividade Física: Interação entre rendimento e saúde. São Paulo: Manole, pp. 5।-78.

Martin D (1991). Zum Belastungsproblem im Kinder- und Jugendtraining unter besonderen Berücksichtung von Vielseitigkeit oder Frühspezialisierung. In $H$ 
Kirchgässner (Hrsg) 40 Jahre Deutsche Hochschule für Körperkultur Leipzig. Academia Verlag Sankt Augustin, pp. I I5- 123.

Martin D (1999). Capacidade de performance e desenvolvimento no desporto de jovens. In Adelino J, Vieira J, Coelho $O$ (Eds) Treino de Jovens. Lisboa: CEFD, Secretaria de Estado do Desporto, pp. 37-59.

Martin D, Carl K, Lehnertz K (1993). Manuale di Teoria dell'Allenamento. Roma: Società. Stampa Sportiva.

Meinberg E (|99|) Die Moral im Sport. Bausteine einer neuen Sportethik. Aachen: Meyer \& Meyer Verlag.

Rahn S (1993) Zu einigen Problemen des allgemeinen Trainings bei der Entwicklung von Leistungsvoraussetzungen im Nawuchsleitungssport. In: J Lenz, K Nitzsche, H Polster (Dir.) Leistungsvoraussetzungen im Nawuchstraining. Sankt Augustin, Academia, pp. 16-25.

Rost K (I995). Le gare nello Sport Giovanile. SdS/Rivista di Cultura Sportiva 32(XIV):6973. Roma: CONI.

Sports Medicine and Performance Commission (2000). Sports Medicine and Performance Commission Position Statement Addressing 10-and-under National Championship. http:// www.avca.org/sportsmed/smpcArticles// Oandunderposition.html.

Thieß G (|99|). Das Nawuchstraining im Spiegel von 20 Jahren "Leistungssport". Fortschritte und Defizite. Leistungssport 6(2|):|2-14. Münster: Deutscher Sportbund, Philippka-Sportverlag.

Thieß G (1995). Die Ausarbeitung einer Wettkampflehre hat begonnen. Leistungssport I (25):5. Münster: Deutscher Sportbund, Philippka-Sportverlag.

Tschiene P (1995). Adaptive Aspekte des Wettkampfs. Leistungssport I (25): I6-19. Münster: Deutscher Sportbund, Philippka-Sportverlag. 
Série

Investigacão

Coimbra

Imprensa da Universidade

2004 